\title{
Editorial
}

\section{Patient assessment of efficacy of pain manage- ment: the fallacy of management by opinion poll}

A $S$ a part of a widespread trend towards the involvement of patients in their medical care, and with the intrusion of marketing concepts into the practice of medicine, patients are increasingly being asked to rate their medical and nursing care. Accreditation groups are increasingly demanding that in addition to the traditional reviews of policy and procedure, there also be evidence that patients are polled for their observations concerning the care which they receive while in hospital. The article in this issue of the Canadian Journal of Anesthesia, " Is self-rated efficacy of analgesia a relevant variable of postoperative pain", reports that there is a poor correlation between efficacy as measured by the sequential ratings of postoperative pain reported by patients, and the patients' evaluation of the efficacy of the pain treatment which they receive. This leaves one with the interesting question of whether or not a patient is the best person to evaluate the quality of the care that they receive. This in turn raises the ancient specter of paternalism (or possibly maternalism).

As part of a longitudinal study of the impact of reengineering on health care, the former ChedokeMcMaster Hospitals ${ }^{2}$ carried out a series of studies in which patients, nursing and medical staff were all asked to rate the quality of the care which the patients had received while they were in hospital. Invariably, patients rated their care more highly than nurses who, in turn, rated the care more highly than did the physicians. It is quite possible that these evaluations reflected varying degrees of knowledge about what care might be possible and, therefore, the standard against which the evaluation was measured may have been different in each case. For example, the patient with (possibly) relatively little specific knowledge about their condition and its appropriate medical treatment, and primed with a great deal of negative publicity about waiting lists, deteriorating hospital care and lack of availability of nursing and medical staff, may have been pleasantly surprised to find physicians present to care for them, nursing staff working around the clock to ensure that their needs were taken care of and, in the end, recovery from their presenting problem. The nursing staff, on the other hand, although they may have felt that they delivered good care when it was possible, may have tempered their evaluations with the knowledge that if more nursing staff had been available certain things would have been done which were not, and that waiting lists for laboratory investigations or delays in obtaining responses from physicians had deleterious effects upon the care which the patients received. Finally, the physicians may have felt that they were prevented from delivering optimum care by budgetary restrictions which required them to use alternative medications (for example lower-priced streptokinase rather than tissue plasminogen activator), or that delays in obtaining diagnostic tests contributed to prolonged hospital stays and possibly delays in achieving definitive diagnoses which would then guide care. In interpreting the data from studies such as this, one is faced with the very difficult question about which evaluation is the most relevant in the course of decision-making around health care. Is it enough simply keep the patients happy, which may

Address correspondence to: Department of Anesthesia, McMaster University, 1200 Main Street West, Hamilton, Ontario, L8N 3Z5 Canada. Phone: 905-521-2100; Fax: 905-523-1224; E-mail: buckleyn@fhs.mcmaster.ca 
require no more than dealing pleasantly with their presenting problems whether or not the management is appropriate? Or, on the other hand, should all care be evaluated against a predetermined objective standard? If so, who should set that standard and who should carry out the evaluations?

In the early days of the organization of our acute postoperative pain service, it was occasionally difficult to convince patients that a modality such as patient controlled analgesia or epidural analgesia might be of interest to them. Many patients reported that they expected to experience pain because they were having surgery, and did not seem to have any particular inclination to search out better forms of management. Many patients focused on the procedure which might be necessary to control pain, for example the insertion of an epidural catheter, and completely overlooked the fact that they were having major intra-abdominal surgery. Some of our first patients who received epidural analgesia for surgery, particularly those who had previously had surgery and experienced less than ideal postoperative pain control, were heard to comment that they 'had no idea it was possible' (to undergo surgery without experiencing severe pain). In a somewhat analogous situation, the population of the British Isles, despite the example of the invading Roman armies with their in-floor central heating, have indicated (by their behaviour in not changing the situation) that they accept as efficacious the (inadequate) heating of their dwellings with open fires, coal grates or meter driven gas jets for generations. One of the problems in asking someone to rate efficacy, is that you don't know what aspect of efficacy is being rated, or against what criterion they are measuring the efficacy which they are rating.

Studies such as Mamie's lead to intriguing questions about the goals of postoperative pain management, and the role of evaluation in medical care. One of the primary goals of instituting improved pain management techniques is the purely humanitarian notion that pain should be treated wherever possible. If that were the only goal, and the purely subjective rating of pain and the patients' subjective evaluation of their care were the only relevant variables, then an evaluation by the patients' rating of satisfaction would probably be relevant and adequate. There are, however, strong suggestions arising out of research into perioperative pain and surgical outcomes that poorly treated pain has an influence upon other morbidity. The physiologic and metabolic consequences of poorly treated pain may have significant effects upon such outcomes as perioperative respiratory or cardiac complications. If that is the case, ${ }^{3-5}$ then some form of evaluation which measures the success of pain treatment against an objective standard, perhaps the complete absence of pain, becomes a crucial element in the management of the postoperative patient and in the evaluation of the efficacy of their post surgical care including pain management.

The use of an appropriate measurement tool is also important. Although there is considerable evidence in the pain literature describing the validity of the visual analog scale (VAS) in pain assessment, the validity of the use of such a scale for the measurement of efficacy has not been established. If patient assessment of efficacy is to become a key element of monitoring or evaluating any aspect of medical practice, then the technique for measuring efficacy should also be well established. At least one hospital ${ }^{6}$ in the course of developing an institutional approach to improved pain management, chose to use actual pain ratings and changes in pain ratings as the dependent measure of the success of their program. This indicates their acceptance of the idea that if you want to measure your success in treating something, you should actually measure a reduction in the thing which you purport to be treating.

While a number of organizations including the American Pain Society, ${ }^{7}$ the American Society of Anesthesiologists, ${ }^{8}$ and the Agency for Health Care Policy and Research (AHCPR), ${ }^{9}$ suggest the implementation of patient satisfaction ratings in their evaluation of care, it is still uncertain whether these evaluations are related to the actual care which is delivered. Ward and Gordon ${ }^{10}$ in their study found no correlation between pain scores and patients' satisfaction with analgesia. The study reported in this journal finds no correlation between ratings of pain intensity and assessment of treatment efficacy. Thus it would seem that there remains considerable work to be done before patients' satisfaction and patient ratings of efficacy can become useful tools in guiding our pain management practices. Furthermore, it raises a question of whether patient ratings of efficacy and patient satisfaction ratings have any relevance at all in the evaluation of any medical services, since the treatment of this most subjective of all problems does not thus far appear to lend itself reliably to patient self evaluation. 


\section{L'évaluation de l'anal- gésie par le patient : l'il- lusion d'un traitement par sondage d'opinion}

Selon une tendance généralement admise d'impliquer les patients dans les soins médicaux qu'ils reçoivent, et avec l'intrusion de concepts marketing en pratique médicale, on demande de plus en plus aux patients d'évaluer leurs soins médicaux et infirmiers. Aussi, on exige davantage des groupes d'accréditation qui, en plus des révisions traditionnelles des politiques et des interventions, doivent s'assurer que des sondages ont été réalisés auprès des patients quant à leurs commentaires sur les soins reçus à l'hôpital. L'article du présent numéro du Journal canadien d'anesthésie, "Is self-rated efficacy of analgesia a relevant variable of postoperative pain» ${ }^{1}$, rapporte qu'il existe une faible corrélation entre l'efficacité telle que mesurée par des estimations séquentielles de la douleur postopératoire décrite par les patients, et l'évaluation faite par les patients de l'efficacité du traitement analgésique qu'ils reçoivent. On peut donc se demander si le patient représente ou non la meilleure personne pour évaluer la qualité des soins reçus. Par ailleurs, la situation soulève le vieux spectre du paternalisme ou, peut-être, du maternage.

Les hôpitaux Chedoke-McMaster ${ }^{2}$ ont effectué une série d'études, faisant partie d'un essai longitudinal sur l'effet de la réorganisation des soins de santé, dans laquelle les patients et le personnel infirmier et médical ont eu à évaluer la qualité des soins reçus par les patients pendant leur séjour hospitalier. La cote accordée par les patients a toujours été plus élevée que celle des infirmières qui, à leur tour, ont donné une meilleure cote que les médecins. Il est possible que ces évaluations traduisent les divers niveaux de connaissances des soins qu'on pourrait offrir et que, par conséquent, la norme d'après laquelle se fait l'évaluation soit différente dans chaque cas. Par exemple, le patient qui a (probablement) peu d'informations sur sa condition et le traitement indiqué, et qui est fortement influencé par l'abondante publicité négative au sujet des listes d'attente, de la détérioration des soins hospitaliers et du manque de personnel infirmier et médical, peut être agréablement surpris de trouver un médecin pour s'occuper de lui, des infirmières qui travaillent vingt-quatre heures sur vingt-quatre pour répondre à ses besoins et, finalement, de se rétablir de sa maladie. Le personnel infirmier, de son côté, même s'il croit avoir donné de bons soins dans la mesure du possible, peut avoir des réserves dans son évaluation sachant que si le personnel avait été plus nombreux certains gestes auraient pu être posés, qui ne l'ont pas été, et que les listes d'attente pour les analyses de laboratoire ou les délais à obtenir des réponses des médecins ont des effets nuisibles sur les soins donnés au patient. Enfin, les médecins peuvent penser qu'ils sont empêchés par des restrictions budgétaires de prodiguer les meilleurs soins, ce qui les oblige à offrir des médications de remplacement (par exemple, de la streptokinase moins chère plutôt qu'un activateur tissulaire du plasminogène), ou que les délais à obtenir les résultats des tests diagnostiques contribuent à prolonger les séjours hospitaliers et, probablement, les délais pour en arriver au diagnostic définitif qui guidera leur intervention. Quand on interprète les données d'études comme celle-ci, on se retrouve confronté à une difficile question, à savoir quelle évaluation serait la plus appropriée au moment de décider du traitement à offrir. Est-ce suffisant de satisfaire tout simplement le patient, ce qui peut n'exiger que de s'occuper agréablement de ses problèmes, que le traitement soit ou non bien adapté? Ou, d'un autre côté, les soins devraient-ils être évalués selon une norme objective prédéterminée? Dans ce cas, qui devra établir cette norme et qui réalisera les évaluations?

Aux premiers jours du service de traitement de la douleur postopératoire aiguë, il était parfois difficile de convaincre les patients qu'une méthode comme l'analgésie contrôlée par le patient ou l'analgésie péridurale puisse leur être profitable. De nombreux patients ont rapporté qu'ils s'attendaient à avoir des douleurs après une intervention chirurgicale et ils ne semblaient pas vouloir chercher de meilleures formes de soulagement. Beaucoup étaient davantage préoccupés par la technique utile à l'analgésie, comme l'insertion d'un cathéter épidural, que par le fait d'avoir subi une opération intra-abdominale majeure. Certains de nos premiers patients qui ont reçu une analgésie péridurale pendant une opération, surtout ceux qui avaient déjà été opérés et avaient fait l'expérience d'analgésie moins qu'idéale, ont dit qu'ils «n'avaient aucune idée qu'il était possible» de subir une opération sans éprouver de douleurs intenses. De façon assez semblable, la population des Iles Britanniques, malgré l'exemple des armées romaines d'invasion avec leur système de chauffage central sous le plancher, a indiqué, en ne changeant pas la situation, qu'elle a accepté comme efficace le chauffage, pourtant inadéquat, de ses habitations avec des feux de cheminées, des foyers au charbon ou des brûleurs à gaz 
et ce, pendant des générations. En fait, quand on demande à quelqu'un d'évaluer l'efficacité, on ne sait pas quel aspect il examine ou sur quel critère il mesure l'efficacité qu'il évalue.

Des études comme celle de Mamie soulèvent des questions dignes d'intérêt au sujet des objectifs du traitement de la douleur postopératoire et du rôle de l'évaluation des soins médicaux. L'un des principaux buts fixés lors de la mise au point d'une technique supérieure de traitement de la douleur est de nature purement humanitaire, à savoir, traiter la douleur autant que possible. Si c'est le seul objectif, et si l'évaluation purement subjective de la douleur et l'évaluation subjective des soins faite par les patients sont les seules variables significatives, une évaluation de la satisfaction selon une cote donnée par les patients pourrait dès lors être appropriée et suffisante. Toutefois, de solides indications provenant de recherches sur la douleur périopératoire et l'évolution postopératoire montrent que la douleur qui n'est pas bien traitée a des effets sur d'autre morbidité. Les conséquences physiologiques et métaboliques de la douleur non soulagée peuvent avoir des effets significatifs sur cette morbidité, comme des complications périopératoires respiratoires ou cardiaques. Si c'est le cas, ${ }^{3-5}$ une certaine forme d'évaluation qui mesure le succès du traitement de la douleur par rapport à une norme objective, comme l'absence complète de douleur, devient alors un élément crucial du traitement postopératoire et de l'évaluation de l'efficacité des soins postchirurgicaux, y compris le soulagement de la douleur.

L'utilisation d'un outil de mesure approprié est aussi importante. Malgré la forte évidence présentée dans la littérature sur la douleur, qui décrit la validité de l'échelle visuelle analogique (EVA) comme outil d'évaluation de la douleur, la validité de l'usage de cette échelle dans la mesure de l'efficacité n'a pas été établie. Si l'estimation de l'efficacité, faite par le patient, doit devenir un élément clé du monitorage ou de l'évaluation d'un aspect quelconque de la pratique médicale, alors la technique utilisée pour mesurer l'efficacité doit aussi être bien déterminée. Dans un hôpital au moins ${ }^{6}$ où on s'emploie à élaborer une méthode pour améliorer le traitement de la douleur, on a choisi d'utiliser les estimations de la douleur réelle et les changements de valeur de ces estimations comme mesure dépendante du succès du programme. On accepte ainsi l'idée que, si on veut mesurer le succès d'un traitement, on doit en réalité mesurer une réduction du problème qu'on prétend traiter.

Nombre d'organisations, y compris l'American Pain Society, ${ }^{7}$ 1'American Society of Anesthesiologists, ${ }^{8}$ et
l'Agency for Health Care Policy and Research (AHCPR), 9 encouragent l'implantation d'un système d'évaluation de la satisfaction du patient dans l'évaluation globale des soins, mais on ne sait toujours pas si ces évaluations sont en lien avec les soins réels qui sont offerts. Ward et Gordon ${ }^{10}$, n'ont pas trouvé de corrélation dans leur étude entre les scores de douleur et la satisfaction des patients à propos de l'analgésie. L'étude citée dans le présent numéro indique qu'on n'a pas trouvé de corrélation entre les estimations de l'intensité de la douleur et l'évaluation de l'efficacité du traitement. Il y a donc beaucoup à faire encore avant que la satisfaction des patients et les estimations réalisées par eux puissent devenir des outils qui serviraient de guide au traitement de la douleur. En outre, l'étude soulève la question de savoir si les estimations de l'efficacité, réalisées par le patient, et les estimations de la satisfaction du patient sont d'une quelconque pertinence au moment d'évaluer quelque service médical que ce soit, puisque le traitement de ce problème des plus subjectifs ne semble pas se prêter de façon fiable, jusqu'ici, à l'auto-évaluation du patient.

\section{References}

1 Mamie C, Morabia A, Bernstein M, Klopfenstein CE, Forster $A$ Treatment efficacy is not an index of pain intensity Can J Anesth 2000; 47: 1166-70.

2 The impact of re-engineering and other cost reduction strategies on the staff of a large teaching hospital. A Longitudinal Study. Medical Care 1999; 37: 556-69.

3 Ballantyne JC, Carr DB, deFerranti, S, et al. The comparative effects of postoperative analgesic therapies on pulmonary outcome: cumulative meta-analysis of randomized, controlled trials. Anesth Analg 1998; 86: 598-612.

4 Beattie WS, Badner NA, Choi PT-L. Effect of postoperative epidural analgesia on cardiac morbidity and mortality: a meta-analysis. Personal Communication (Submitted) 2000.

5 Bode RH Jr, Lewis KP, Zarich SW, et al. Cardiac outcome after peripheral vascular surgery. Comparison of general and regional anesthesia. Anesthesiology 1996; 84: 3-13.

6 Ryan M, Ambrosio D, Gebhard C, Kowalski J. Pain management: an organizational commitment. (Abstract) Pain Management Nursing 2000; 1: 34-9.

7 Max M. American Pain Society quality assurance standards for relief of acute pain and cancer pain. In: Bond M, Charlton J, Woolf C (Eds.). Proceedings of World Congress on Pain. Amsterdam: Elsevier, 1991: 186-9.

8 American Society of Anesthesiologists Task Force on Pain Management, Acute Pain Section. Practice guidelines for acute pain management in the perioperative setting. Anesthesiology 1995; 82: 1071-81. 
9 Agency for Health Care Policy and Research (AHCPR). Acute Pain Management: operative or medical procedures and trauma. Rockville, MD: Department of Heath and Human Services, 1992: Publication No. 92-0032.

10 Ward SE, Gordon D. Application of the American Pain Society quality assurance standards. PAIN 1994; 56 : 299-306. 